\title{
Bio- and Nanotechnology as the Key for Clinical Application of Salivary Peptide Histatin: A Necessary Advance
}

\author{
Carolina Reis Zambom *, Fauller Henrique da Fonseca $₫$ and Saulo Santesso Garrido * \\ Department of Biochemistry and Organic Chemistry, Institute of Chemistry, UNESP-Sao Paulo State University, \\ Araraquara/SP 14800-060, Brazil; fauller.henrique@unesp.br \\ * Correspondence: carolina.zambom@unesp.br (C.R.Z.); saulo.santesso@unesp.br (S.S.G.)
}

Received: 16 June 2020; Accepted: 8 July 2020; Published: 10 July 2020

check for updates

\begin{abstract}
Candida albicans is a common microorganism of human's microbiota and can be easily found in both respiratory and gastrointestinal tracts as well as in the genitourinary tract. Approximately $30 \%$ of people will be infected by C. albicans during their lifetime. Due to its easy adaptation, this microorganism started to present high resistance to antifungal agents which is associated with their indiscriminate use. There are several reports of adaptive mechanisms that this species can present. Some of them are intrinsic alteration in drug targets, secretion of extracellular enzymes to promote host protein degradation and efflux receptors that lead to a diminished action of common antifungal and host's innate immune response. The current review aims to bring promising alternatives for the treatment of candidiasis caused mainly by $C$. albicans. One of these alternatives is the use of antifungal peptides (AFPs) from the Histatin family, like histatin-5. Besides that, our focus is to show how nanotechnology can allow the application of these peptides for treatment of this microorganism. In addition, our intention is to show the importance of nanoparticles (NPs) for this purpose, which may be essential in the near future.
\end{abstract}

Keywords: Candida albicans; antifungal peptides; nanoparticles; histatin-5

\section{Introduction}

Candida spp. are reported as the most common fungal pathogens with the ability to cause superficial infections to progress to systemic infections in human hosts, especially those who are immunocompromised [1]. This class of microorganism is responsible for major systemic fungal infections representing high mortality rates and generating expressive healthcare costs worldwide [2]. Candida albicans is the most important species because it is more frequently isolated in humans and cause $\sim 1.5$ million deaths per year around the world [3]. In addition, this species is quite versatile, being able to develop in environments with different conditions such as different nutrient availability and different oxygen rates, which demonstrates an incredible ease of adaptation [4].

As a commensal pathogen, C. albicans is able to change its morphology from yeast to hyphae and become more infectious depending on the host's immune response. This set of characteristics has a direct influence on the virulence of this species, which has been increasing progressively over the years [5]. The hyphae morphology represents an important virulence factor for this pathogen [6] besides the ability to form biofilm. Those characteristics make this species even more difficult to eradicate [2].

Nevertheless, there are several reports of adaptive mechanisms that this species can present when exposed to conventional antifungal agents, such as fluconazole. Some of these mechanisms are related to stress responses, intrinsic alteration in drug target and enzymatic degradation that permit this 
microorganism to survive even during antibiotic treatment [7]. For this reason, candidiasis caused by C. albicans is currently prevalent, especially in hospitalized patients. Medical interventions such as chemotherapy for cancer treatment and immunosuppression for transplantation makes the patient more susceptible to C. albicans infections [8].

Therefore, the search for new antifungal drugs is very important and must be constantly developed. A promising alternative is the use of bioactive peptides which naturally participate in innate immune response of the human body. An example of this are the Histatin peptides found in human saliva. This histidine-rich class of peptides presents antifungal activity in addition to playing an important role in wound healing and oral re-epithelization [9]. Histatin-5 is the most potent antifungal peptide in the Histatin family [10] and has a wide action against pathogenic fungi, including C. albicans.

However, this peptide has not yet been used in therapy. One reason for this is its enzymatic degradation when it is present at the site of action. Therefore, the purpose of this review is to highlight some mechanisms that confer resistance to $C$. albicans and the importance of this peptide in the eradication of this microorganism. We described here what has been developed in the last three years regarding this peptide and its use. In addition, this review proposes the use of nanotechnology as an important tool that can facilitate the clinical use of this peptide. In fact, the use of nanotechnology and drug delivery systems can lead to a step forward in the field of antifungal therapy to allow its use without the risk of enzymatic degradation, increasing its time of residence at the site of action and providing a prolonged and non-cytotoxic treatment.

\section{Candida albicans: Virulence Factors and Resistance}

Candida albicans is a diploid polymorphic fungus that can switch between the yeast and hyphal growth modes and exists as a common member of the human microflora, asymptomatically colonizing the skin and the gastrointestinal, respiratory and genitourinary tracts as a commensal microorganism [11,12]. The commensal state of $C$. albicans is maintained by some factors as intact epithelial barriers, innate immune system responses and coexisting microflora, but in situations in which these factors are absent or weakened, C. albicans proliferation is favored and this fungus can become an opportunistic microorganism, progressing from superficial infections to systemic infections that can lead to death [12,13]. Risk factors for Candida spp. superficial or systemic infections can be divided in three categories: (I) factors that promote colonization by Candida, for example broad-spectrum antibiotics therapy; (II) factors that cause immunosuppression, such as organ transplant, HIV, neutropenia, use of chemotherapeutic agents, age, malnutrition; and (III) factors that provide a route for Candida infection, for example, surgical procedures, parenteral nutrition, hemodialysis, mechanical ventilation and catheters $[14,15]$.

In order for C. albicans to colonize and persist in a host, as a commensal or as a pathogen, its adhesion to a mucosal surface is essential. The first step is overcoming the mucous barrier that protects the host epithelium in order to access it and promote a physical interaction between the epithelial cells and the fungus [16-18]. The initial interaction is thought to involve the yeast form, but studies in murine models showed that yeast and hyphal morphologies can be observed in the gastrointestinal tract during commensal colonization [18,19]. Both morphologies have developed mechanisms to promote the adhesion to the epithelial tissue; the adhesins proteins are the most important ones. The agglutinin-like sequence (Als) proteins Als5p and Als3p mediate the adhesion of yeast cells and hyphal form to the host epithelium, respectively [20,21]. These proteins are linked to the $\beta-1,6$-glucans present in the fungal cell wall and, along with other proteins of the Als family, are responsible for recognizing and binding to different surfaces, from epithelial tissues to abiotic surfaces, such as dentures and medical devices [22]. Besides the importance of this family of protein for C. albicans adhesion to the host epithelial tissues, they also participate in the adhesion of other microorganisms to C. albicans hyphae, like other Candida species and Streptococcus oralis [23,24]. Furthermore, the amyloid forming region (AFR), located in the N-terminal domain of Als proteins, allows the interaction between Als of different cells, which is important for the aggregation of C. albicans cells and hyphae [25]. 
Once C. albicans is adhered to the host epithelium, there are two mechanisms by which it can be internalized. The first process, which allows internalization of viable and nonviable fungi, is called induced endocytosis. It is initiated by the interaction between fungal proteins, like the invasin Ssa1p or adhesin Als3p, and host E-cadherin or EGFR/Her2 complexes. This binding activates a chlatrin-dependent mechanism that induces actin cytoskeleton remodeling, producing pseudopods responsible for pulling the fungus into the host cells [26-28]. The second process, called active penetration, requires metabolically viable fungi. It is a combination of the mechanical tension caused by the elongation of hyphal tips and the action of secreted hydrolytic enzymes and cytolytic peptides, which facilitate extension of the hyphae through or between epithelial cells [29,30]. C. albicans is known to secrete 255 enzymes that act directly as virulence factors, but two classes of extracellular enzymes have a major role in adherence, tissue invasion and nutritional acquisition by C. albicans, aspartyl-proteinases (SAPs) and phospholipases [28,31,32]. The SAPs secreted by C. albicans have the ability to degrade a broad-range of host proteins: Sap2p and Sap5p are related to degradation of E-cadherin and mucins present in the gastrointestinal epithelium, facilitating hyphae penetration $[33,34]$. These proteinases are also involved in the degradation of host defense factors, like antibodies and antimicrobial peptides [16,35]. For example, it was observed in vitro that the killing ability of the peptide histatin-5, in salivary concentrations, was inversely proportional to C. albicans cell density, due to degradation by Sap9p [36]. The cell surface protein Msb2p is also responsible for degrading antimicrobial peptides, such as histatin-5 and LL-37 [37]. Moreover, Moyes et al. identified a cytolytic peptide, secreted by C. albicans only in the presence of epithelial cells. The C. albicans hyphal-specific cell elongation 1 gene codes for the protein Ece1p, comprised by 271 amino acids, which is cleaved by Kex2 protease into eight secretory peptides, being the fungal cytolytic peptide one of these peptides. This peptide was called candidalysin and it was pointed by the authors as the most important fungal cytolytic peptide toxin in the process of mucosal infection by C. albicans [38]. The peptide has the ability to permeabilize epithelial cell membranes, damaging it through a "carpet-like mechanism", that leads to enzymatic and ionic effluxes, besides stimulating cytokine secretion [38]. Besides the importance they have for Candida pathogenicity, the invasion and colonization of the human tissue by some species of Candida spp. may also be a possible trigger for autoimmunity issues. There are some reports of celiac disease (CD) [39], food allergy [40] and inflammatory bowel diseases (IBD) associated with $C$. albicans infections [41]. Some hypotheses describe that C. albicans presents hyphal wall proteins that show similarities with T-cell gliadin epitopes [42]. The protein Hwp1, expressed by C. albicans, presents sequence analogy with the gluten protein gliadin. Due to the Hwp1 protein being also a substrate for the transglutaminase enzyme, some cases of $C$. albicans infection could be associated with Celiac disease [42]. In addition, it was also reported that microorganisms like C. albicans can remodel some immune cells to induce memory and Trained Immunity (TRIM) associated with some types of food allergy. In this case, $\beta$-glucan, an integral cell wall component of $C$. albicans, can lead to TRIM mediated activation of dectin-1 receptor and the mTOR pathway [40].

The ability of $C$. albicans to form biofilms also has clinical significance. Biofilms are surface-associated microbial communities, which show increased expression of virulence and drug-resistance factors, like adhesins and efflux pumps, leading to alterations in stress response and decreased susceptibility to phagocytosis when compared to the microorganism planktonic form [32,43]. Besides the drug-resistance factors, the extracellular matrix is also responsible for preventing bioavailability of antifungal drugs [44]. Candida biofilms can be associated to abiotic surfaces, like medical devices, where they can lead to the development of bacterial infections by Staphylococcus aureus and Pseudomonas aeruginosa in the case of mechanical ventilation, for example [45].

Regarding the oral cavity, it is possible to observe the formation of monomicrobial and polymicrobial biofilms on the oral epithelium or dentures surfaces, for example [46]. Dental caries is the most common oral disease and is associated to the bacteria Streptococcus mutans. Evidence points to C. albicans having a potential role in dental caries, since dental biofilms of associated S. mutans-C. albicans are commonly found. Moreover, both species are able to produce and tolerate acid compounds responsible for damaging 
the tooth [47-49]. Some works also exploited the association of C. albicans to Streptococcus oralis. In vitro studies conducted by Cavalcanti et al. showed greater levels of filamentation and biofilm development by $C$. albicans when $S$. oralis was present [50]. Xu et al. observed facilitated C. albicans invasion in mucosal tissue, mouse tongue and kidney when associated to $S$. oralis, related to an increase in the degradation of E-cadherin by calpain [51]. S. oralis was also shown to induce expression of Candida genes and proteins that promote bacteria adherence to fungal hyphae [24]. Streptococcus gordonii is also capable of forming biofilms in association to C. albicans, which provides resistance to antimicrobial treatment for both microorganisms [52,53]. In contrast, the interaction between C. albicans and the species Pseudomonas aerugionosa or Fusobacterium nucleatum seems to be antagonistic. Studies involving P. aerugionosa showed inhibition of Candida hyphae development [54]. The interaction between C. albicans and F. nucleatum reduced the ability of both the microorganisms to escape from phagocytosis [55,56]. These data show the importance of inter-species interactions and microbial equilibrium in the maintenance of good oral health.

The first line of defense against $C$. albicans are the oral epithelial cells which not only act as a physical barrier, but also can minimize adherence, by processes like desquamation, upon recognizing C. albicans hyphae $[57,58]$. Saliva also represents an important factor on preventing C. albicans colonization and adherence, either by mechanical removal of Candida cells or by the many antimicrobial peptides (AMPs) in its composition [57,59]. The most outstanding peptides related to Candida control in the oral cavity are the histatins, defensins, cathelicidins and lactoferrin [60]. The first ones are a family of histidine-rich cationic peptides, part of the defensins group, which will be better described ahead. Defensins are cysteine-rich peptides produced by neutrophils ( $\alpha$-defensins) and epithelial cells ( $\beta$-defensins) [61]. There is only one human cathelicidin known, called LL-37, that impedes Candida adhesion by interacting with cell wall components of the fungus and, additionally, is capable of inducing chemokines [62]. Finally, lactoferrin has the ability to disrupt the fungal plasma membrane and alter iron availability within the fungal cell $[63,64]$. The Th1 and Th17 lymphocytes are involved in adaptive immunity, and the last ones are suggested to be responsible for long-term immunity to oral mucosal infections $[58,65,66]$. Those facts are associated with a greater incidence of oral-related C. albicans infections on immunodeficient or immunosuppressed patients. For instance, studies reported higher levels of the C. albicans specifically IgA in HIV+ individuals, who show lower levels of the peptide histatin-5 and depleted Th17 lymphocytes $[67,68]$.

In terms of therapeutic strategies to treat fungal infections, azoles, echinocandins and polyenes are available to treat systemic infections, while all the antifungals available in the market to treat mucosal candidiasis target the ergosterol present in the cell membrane $[69,70]$. The extensive and frequent use of antifungals as prophylactic or therapeutic treatments of humans and animals, in agriculture, wood and textile industries, led to the development of multidrug-resistant strains of medically relevant fungi, being the resistance to azoles and echinocandins the most reported [71-73]. While echinocandins show fungicidal activity against most of Candida species, azoles are fungistatic, providing the possibility of acquired resistance development [74,75]. The prevalence of fluconazole resistance in C. albicans is low, but higher rates are observed for Candida glabrata with rates up to $13 \%$, for Candida auris which rates near 93\% resistance, and Candida krusei, which has shown innate resistance [76-78]. Some of the reported resistance mechanisms involve amino acid substitutions on the molecular targets of the antifungals-like that observed in the Fks subunits of glucan synthase, target of the echinocandins [79]—or in the enzyme 14-alpha demethylase, targeted by azoles [80,81]. Metabolic upregulation and overexpression of genes also contribute to resistance mechanisms. The increased chitin synthesis was observed for echinocandin-resistant Candida species; in the same way, overexpression of the ERG11 gene, encoding for the enzyme 14-alpha demethylase, is associated to azole-resistant fungi, along with other mutations [8,82]. Mutations in the gene ERG3 resulting in a loss of function of the enzyme sterol $\Delta^{5,6}$-desaturase lead to cross-resistance to azoles and polyenes, since the cell circumvents the production of toxic methylated sterols and also accumulates alternative membrane sterols to replace ergosterol $[83,84]$. Finally, efflux transporters are a relevant feature in the resistance mechanisms, 
since they do not allow the drug to accumulate intracellularly. In Candida species, three proteins are related to fluconazole resistance: the ATP-dependents Candida drug resistance proteins 1 and 2 and the proton-motive force- driven protein Mdr1p [85-87].

The emergence of resistant Candida species leads to a difficulty to find new drugs with absence of host toxicity [70]. One way to face this obstacle are the antimicrobial peptides (AMPs) that are part of the innate defense mechanisms of the host and could play an important role in the fight against fungal infections.

\section{Histatins and Their Role in the Antifungal Treatment}

Several AMPs play an important role in the innate immune response of living organisms. These peptides are present in all human systems and tissues and continuously protect against fungi, bacteria, viruses, protozoa and other parasites [88]. Peptides such as $\alpha$ and $\beta$ defensins, cathelicidins and histatins are part of the Antifungal Peptides (AFPs) which widen antimicrobial action [89].

The peptides of the Histatin family are the most abundant group of proteins present in human saliva. They are histidine-rich peptides secreted by the parotid and submandibular glands and were first described by Oppenheim et al. [9]. These peptides have a strong antifungal and antibacterial activity against many oral pathogens species and are important for the maintenance of the oral homeostasis, helping in wound healing and oral re-epithelization $[90,91]$. Histatin-1, -3 and -5 are the three major histidine-rich peptides present in human saliva [9]. Histatin-5 is a proteolytic product of histatin-3 and is the peptide with the greatest antifungal action in the Histatin family. This peptide has 3 to $4 \mathrm{KDa}$, a sequence of 24 amino acid and positive charge in physiological $\mathrm{pH}$. This peptide assumes an $\alpha$-helix structure in DMSO (dimethylsulfoxide) and in TFE (trifluorethanol)/water, but when in water it assumes a random structure [92]. Histatin-5 has a wide antifungal action against pathogenic fungi, including Candida albicans [93] and Candida glabrata [94]. Recent studies have shown that histatin-5 is able to inhibit the growth of C. albicans strains in concentrations from 25 to $800 \mu \mathrm{g} \mathrm{mL}^{-1}$ [95], with a minimum inhibitory concentration (MIC) of 8-16 $\mu \mathrm{g} \mathrm{mL}-1$ [96].

Although its mechanism of action is not fully understood yet, studies indicate that the ATP efflux and oxidative stress caused by interaction with mitochondria cells lead the microorganism to death $[10,90,97]$. In addition, studies have shown that the targets of this peptide are intracellular and unlike others antimicrobial peptides, pore formation and membrane lysis caused by histatin- 5 have been disproved. Histatin- 5 is able to penetrate the cell of $C$. albicans through the membrane receptor Ssa $1 / 2$ and glycans and its internalization mechanism is energy dependent [11]. This membrane receptor on C. albicans cells works as a cell market for its action and makes this peptide selective without cytotoxicity for human cells [98].

A recent study conducted by Basso et al. showed that the ATP efflux caused by histatin- 5 is slow and prolonged and leads to a slower cell death compared to the peptide RTD-1 used in this study [99]. Despite that, recently Pathirana et al. proved the effectiveness of this peptide in inhibiting seven resistant strains of $C$. auris, a multidrug resistance microorganism. Histatin-5 inhibited from 55 to $90 \%$ of $C$. auris cells in a dose of $7.5 \mu \mathrm{M}$ [100]. However, it is not only against fungi that this peptide has antimicrobial activity. Du et al. demonstrated that histatin- 5 is able to inhibit multi-drug resistance ESKAPE pathogens (Enterococcus faecium, Staphylococcus aureus, Klebsiella pneumoniae, Acinetobacter baumanni, Pseudomonas aeruginosa and Enterobacter species) [101]. Only $30 \mu \mathrm{M}$ of histatin-5 was enough to inhibit five of the six tested pathogens. Differences in the mechanism of action of this peptide were also found among these pathogens. For E. faecium and E. cloacae, the peptide needs to be internalized by an energy-dependent manner; for $p$. aeruginosa and A. baumanni, the rapid antibacterial action is related with membrane pore formation and lysis [101]. This result, together with others described here, proves that this peptide has broad antimicrobial activity and multiple mechanisms of action.

In 2014, Puri and Edgerton proposed that histatin-5 antifungal activity could also be related to its ability to bind metals [97] with two specific regions preferred for metal binding. The $\mathrm{N}$-terminal region shows an ATCUN motif binding, in which Cu (II) and Ni (II) can be connected. And the C-terminal 
region contains Zn (II) binding motif [102]. The study conducted by Conklin et al. demonstrated that the binding with $\mathrm{Cu}$ (II) can improve the antifungal action of the peptide showing an $\mathrm{IC}_{50}$ below $5 \mu \mathrm{M}$. The same study also showed that the first 12 amino acids play an important role in binding to $\mathrm{Cu}$ (II) [103]. In addition, a connection with $\mathrm{Fe}$ (III) was also reported, and this metal was able to induce $\alpha$-helix formation, but this is not related to an antifungal activity increase [104].

Even though this peptide shows several mechanisms of action and several options to enhance its antifungal activity, resistance in some $C$. albicans strains against histatin-5 has been reported. An example of this mechanism is related to histatin- 5 proteolytic cleavage by aspartic proteases as well as the linkage with the membrane protein Msb2 that prevents its internalization $[36,105,106]$. Li et al. also demonstrated that polyamine efflux transporters, like FLU1, are able to cause the efflux of histatin-5, preventing its antifungal action [107]. However, that study also noted that the appearance of the mutation that leads FLU1 to promote histatin-5 efflux is not caused by overexposure to this peptide. Hampe et al. also noted the same when investigating transcription factors that regulate FLU1 expression [108]. Although the FLU1 mutation is not associated with overexposure to histatin-5, it is associated with overexposure to fluconazole. It is interesting to note that excessive exposure to conventional drugs promoted not only resistance to these treatments, but also resistance to an innate host defense mechanism such as the peptide histatin-5 [108].

As already mentioned in this review, the emergence of resistant strains brings up a serious public health problem due to the existence of only four classes of drugs available for treatment (azoles, echinocandins, polyenes and flucytosine) [109]. Even though there have been reports that some strains of $C$. albicans are resistant to histatin-5, this molecule is still attractive for clinical treatment against resistant pathogens. The advantage of using AFPs is the possibility of modifying their amino acid sequence to create analogues and hybrids. These modifications could improve their antifungal activity and also allow the peptide to avoid the pathogen resistance mechanisms.

Dh- 5 was one of the first histatin- 5 analogs to be produced. Its amino acid chain corresponds to the C-terminal sequence of histatin-5 known to be responsible for the antifungal action (residues 11-24) [110]. However, this peptide did not show an increase in its activity and for this reason the dhvar1 and dhvar2 analogues were produced. The amino acid sequence of these peptides was modified in order to increase their hydrophobicity and to assume an $\alpha$-helix structure. These modifications promoted a 6-fold increase activity by showing a pore formation mechanism of action [110-112]. This mechanism of action differs these analogues from the original peptide histatin-5, which has no membranolytic action. Thus, this hydrophobic characteristic allows these analogues to act against other pathogens such as Torulopsis glabrata, Prevotella intermedia, Streptococcus mutans, and methicillin-resistant Staphylococcus aureus $[111,113]$.

Besides modifying the amino acid sequence, another widely used strategy to improve peptide properties is the fusion between two different peptides. Lu et al. produced the chimeric peptides cCF10-dhvar4 and cOB1-dhvar4 that showed an $\mathrm{LC}_{50 \mathrm{~S}}$ of $1 \mu \mathrm{M}, 10$ times greater than the original dhvar4 [114]. Another example of this would be the combination of histatin-5 and halocidin demonstrated by Han et al. [96]. This combination produced three hybrid peptides named di-PH2, di-WP2 and HHP1, which showed MICs of 1-2, 2-4 and 2-4 $\mu \mathrm{g} \mathrm{mL}^{-1}$, respectively [96]. The hybrid peptide di-WP2 did not present cytotoxicity and maintained its action even in a medium with $150 \mathrm{mM} \mathrm{NaCl}$ [96]. Results like this demonstrate that the fusion of two different peptides results in an improvement not only in the antifungal activity of histatin-5, but also in the gain of other functions provided by the union of two different molecules. However, it is not only the increased antimicrobial action that the production of hybrid or chimera peptides can provide. By joining two fragments or two different peptides, the result can produce a new molecule that has a dual-effect or synergic effect. The hybrid peptide DR9-RR14 produced by Basiri et al. joined the active fragment of histatin-3 with the active fragment of statherin, resulting in a peptide with the potential to prevent tooth demineralization and antimicrobial activity [115].

Perhaps the most important advantage provided by the production of histatin- 5 hybrids and analogues is to avoid resistance mechanisms showed by C. albicans. Ikonomova et al. proposed the replacement 
of two lysines (positions 11 and 17) for two arginines in the histatin-5 sequence. This modification increased the antifungal activity and provided resistance to $C$. albicans proteolytic cleavage $[116,117]$. The same result was observed by Jephthah et al. when producing a hybrid peptide of histatin- 5 and spermidine. The Hst4-15-Spd peptide showed an increase in its antifungal activity in addition to resistance to aspartic proteases secreted by C. albicans [118]. As described in this topic, there are countless histatin-5 analogs already produced and with proven effectiveness for inhibiting C. albicans growth. The analogues mentioned here, and their amino acid sequence, can be seen in Table 1. The produced analogues show extremely important characteristics for their clinical use, such as a low dose of action and non-cytotoxicity. However, they are not yet used in therapy, and there are only few reports of in vivo studies.

One reason for this is that histatin- 5 and its analogs are susceptible to enzymatic degradation when used in the human body. Moffa et al. found that histatin- 5 is the major portion of the glandular proteins but disappear rapidly when in the whole saliva [119] and the cause of this difference is based on the proteolytic cleavage. Thus, its action is reduced or inactivated and its use to treat fungal infections in the oral cavity is difficult. In summary, to make possible the use of this peptide and its analogs, it is necessary to develop strategies that allow its application at the site of action. Such a strategy should protect the peptide against enzymatic degradation and provide a longer residence time at the site of action. As suggested in some studies, the use of nanotechnology to produce protein delivery systems can ensure the biological functions of histatin- 5 and its analogues and promote its use for clinical treatment.

Table 1. Name and amino acid sequence for the analogues and hybrids peptides based on Histatin-5 primary structure.

\begin{tabular}{|c|c|c|}
\hline Name & Sequence & Reference \\
\hline dh-5 & KRKFHEKHHSHRGY & \multirow{3}{*}{ [111] } \\
\hline dhvar1 & KRLFKELKFSLRKY & \\
\hline dhvar2 & KRLFKELLFSLRKY & \\
\hline dhvar4 & KRLFKKLLFSLRKY & \multirow{5}{*}{ [114] } \\
\hline cCF10 & LVTLVFV & \\
\hline cOB1 & VAVLVLGA & \\
\hline cCF10-dhvar4 & LVTLVFVKRLFKKLLFSLRKY & \\
\hline cOB1-dhvar4 & VAVLVLGAKRLFKKLLFSLRKY & \\
\hline P113 & AKRHHGYKKFH & \multirow{6}{*}{ [96] } \\
\hline $15 \mathrm{Hc}$ & ALLHHGLNCAKGVLA & \\
\hline $18 \mathrm{Hc}$ & WLNALLHHGLNCAKGVLA & \\
\hline PH2 & AKRHHGLNCAKFH & \\
\hline HHP1 & WLNALLHHGYKRKFH & \\
\hline WP2 & WLNAKRHHGYKCKFH & \\
\hline Statherin & DSpSpEEKFLRRIGRFGYGYGPYQPVPEQPLYPQPYQPQYQQYTF & \multirow{3}{*}{ [115] } \\
\hline Histatin-3 & DSHAKRHHGYKRKFHEKHHSHRGYRSNYLYDN & \\
\hline DR9-RR14 & DSpSpEEKFLRRKFHEKHHSHRGYR & \\
\hline Hst $_{4-15}$ & AKRHHGYKRKFH & \multirow{3}{*}[118,120]{} \\
\hline Spermidine & GGG-spermidine & \\
\hline Hst $_{4-15}-\mathrm{Spd}$ & AKRHHGYKRKFH-GGG-spermidine & \\
\hline Histatin-5 & DSHAKRHHGYKRKFHEKHHSHRGY & \multirow{2}{*}{ [117] } \\
\hline K11R-K17R & DSHAKRHHGYRRKFHERHHSHRGY & \\
\hline
\end{tabular}

\section{Nanoparticles as a Strategy to Allow Histatins' Clinical Application}

For the last 10 years, the advancement of nanotechnology has allowed the emergence of nanoparticles (NPs), that are able to incorporate bioactive molecules and direct their delivery to the site of action. NPs can be defined as ultra-dispersed supramolecular structures, which range in size from 10 to $1000 \mu \mathrm{m}$ [121]. The drug can be encapsulated, dissolved, trapped or attached to the structure of the nanoparticle, which 
plays an important role in the delivery of drugs in clinical applications. The use of NPs can improve solubility, decrease toxicity, increase therapeutic doses without a risk of side effects, increase bioavailability and residence time at the action site and protect drugs against enzymatic degradation [121]. For this reason, the use of NPs is advantageous and can allow the application of AMPs with therapeutic action in clinical treatments.

An example is the liposome loaded with peptide LL-37, which provided a reduction in its cytotoxicity and increased its effectiveness as an antiviral, being promising for the treatment of HSV-1 in humans [122]. The use of liposomes loaded with the peptide ghrelin promoted its protection against enzymatic degradation by trypsin and carboxylesterase [123], and allowed the nasal application of this peptide to treat cachexia, an extreme weakness that affects hospitalized patients with chronic diseases. Other NPs have also been used to protect and improve the action and bioavailability of AMPs. Polymeric NPs produced with cellulose, chitosan and poly(lactic-co-glycolic) acid (PLGA) were used to protect peptides and proteins from degradation by digestive enzymes [124]. Perfluorocarbon NPs loaded with thrombin inhibitor peptide improved its antithrombotic activity in vivo [125]. Chitosan NPs loaded with nisin increased its antimicrobial activity against S. aureus and Listeria monocytogenes [126]. There are many other examples that prove that the use of NPs loaded with peptides is a strategy capable to promote their therapeutic use.

However, NPs are rarely used with peptides and the few drugs available are in the early stages of development [124]. There are even fewer studies involving NPs and peptides from the histatin family. These peptides have a great antifungal action and play an important role in regulating oral homeostasis, but, as already described in the previous item, they undergo enzymatic degradation at their site of action. For this reason, the combination of these peptides with NPs emerges as a strategy to prevent them from degradation and to increase the residence time in their site of action.

Although there are not many reports of the incorporation of these peptides in NPs, there are recent reports of the use of histatin-1, -5 and some of their structural analogues being incorporated into mucoadhesive hydrogels. The incorporation of these peptides in hydrogel allows their application in the oral mucosa and helps prevent and treat oral candidiasis. Their incorporation also promotes the re-epithelialization and wound healing in the oral cavity [127-129]. Lin et al. incorporated histatin-1 in chitosan hydrogel and observed a prolonged release that generated increased cell adhesion, migration and angiogenesis, important factors for wound healing [127].

The incorporation of histatin- 5 in hydroxypropyl methylcellulose (HPMC) hydrogel demonstrated efficacy for the treatment of oral candidiasis in vivo. The HPMC hydrogel showed slow release with rapid antifungal action [128]. The same HPMC hydrogel was used to incorporate K11R-K17R, an analogue of histatin- 5 with superior antifungal activity. The hydrogel was effective in inhibiting resistant strains of C. albicans [129]. The wide action of this new analogue was demonstrated through its incorporation in HPMC hydrogel and use for the treatment of denture stomatitis in vivo. The formulation was effective to prevent biofilm formation in denture devices [130]. This result is important since as patients who wear dentures are affected by $C$. albicans repeatedly. The infection by $C$. albicans happens because it is common for the microorganism to form biofilms and colonize the surface of the denture, which becomes a source of contamination for the palate tissue, even after treatment with conventional antifungals.

Thus, the complete eradication of the microorganism from the denture is extremely important, as this is the only way to avoid recolonization [130]. In the search for a way to prevent the colonization of $C$. albicans in the denture, Wen et al. developed a material composed by layers of histatin- 5 alternated with hyaluronic acid [131]. With its outermost layer composed of histatin-5, the developed material showed "fungal repellent" ability and prevented the formation of biofilm. A similar study was also carried out by Bates et al. who added histatin- 5 to denture adhesive material, and observed that the peptide lost its antifungal action, promoting $C$. albicans growth [132]. The authors pointed out that this inactivation may be related to the use of denture adhesive, which may hinder the action of natural peptides present in saliva and responsible for the body's innate immune response. However, another possibility would be the retention of the peptide inside the matrix of the adhesive, which would block 
its release and consequently its action. This is possible because, as pointed out by Wen et al., when the histatin-5 layer was formed more inside its material, the antifungal action did not occur. Thus, the best alternative for treatment and prevention of oral candidiasis or denture stomatitis would be the use of systems that allow the release of the peptide or its use as external coating, facilitating its contact with the microorganism and causing its death.

A novel strategy in the development of NPs is their functionalization with a molecule that directs them to the target. This strategy was used by Park et al. who functionalized chitosan NPs with histatin-5 [98]. This peptide is able to penetrate the C. albicans cells through an SSa1/2P receptor that directs the NPs to its target. Once in contact with the cell, the NPs release their internal content composed with amphotericin B (AmB), which with histatin-5 causes the death of the yeast. This was the first time that this antifungal peptide was used to functionalize NPs, and the strategy was successful. The peptide was used as a target and also had a synergistic effect with AmB. In addition, AmB showed low cytotoxicity and great efficiency for acting directly on its target. This study shows a new possibility for histatin-5 and its analogues that can be used to functionalize NPs, an area that is still little explored. Some analogues of this peptide have greater antifungal potential such as P113 [133]. This peptide is smaller than histatin-5, and with only 12 amino acids, it is easier to be produced and used to target NPs, which increases its antifungal potential and promotes its action directly on the target cell.

The association of histatins peptides into NPs is still little explored. Most of the new technologies proposed involving the incorporation of this peptide directly into hydrogels and as a coating for dental materials. However, the application of these hydrogels in the oral cavity must be properly studied, as several factors such as salivary flow, swallowing and chewing and the frequent movement of the tongue can quickly remove the product from its place of action, generating a loss of its activity. Another strategy that keeps these peptides in contact with their site of action and protected from enzymatic degradation is the development of liposomes loaded with histatin-5. Liposomes are nanostructured systems formed by the self-organization of phospholipids in bilayers [134]. Histatin-5loaded liposomes were able to preserve the antifungal action of the peptide and control C. albicans growth for $72 \mathrm{~h}$. In addition, liposomes were able to release their content for a prolonged time [134]. Although complementary tests are needed, such as system degradation in human saliva and in vivo tests, liposomes have proven to be a suitable system for loading the peptide and to be used in the treatment of oral candidiasis.

As highlighted here, although histatin- 1 and histatin- 5 have wide potential for oral re-epithelialization, cell migration and adhesion and antifungal activity $[127,129,130]$, there are still problems that must be solved for their appropriate application. Hydrogels produced with chitosan and HPMC are certainly a strategy that solves some problems for the application of these peptides, as well as the coating of dental materials is also a solution to keep the peptide in contact with its place of action. However, there is a lack of studies on the incorporation of these peptides in NPs, which, due to their unique characteristics, are a very attractive tool and helps overcome the barriers for histatin to be used in clinic and therapy.

\section{Conclusions}

As described here, C. albicans is a versatile microorganism that can adapt to different environments and colonize the host's tissue under certain conditions. Some strategies that make this possible are the yeast to hypha transition, the production of proteins that promote its adhesion and invasion to the host cells and the biofilm formation. The Als proteins, specifically the proteins Als5p and Als3p as well as invasin Ssa1p and adhesin Als3p, are important virulence factors that promote cell adhesion and cell invasion, respectively. Besides that, C. albicans already shows mechanisms that confer resistance to some classical antifungals like fluconazole. Some of these mechanisms are efflux transporters that do not allow the accumulation of the drug intracellularly. In addition, Candida species presents ATP-dependent proteins 1 and 2, and the 1 proton-motive force-drive protein Mdr1p. Those proteins are related to fluconazole resistance and play an important role in increasing the virulence factors when expressed for the microorganism. Other mutations like increased chitin synthesis and overexpression of the ERG11 are associated with resistance mechanisms to echinocandins and azoles, respectively. 
However, the most important and that requires concern are factors that confer resistance to some innate immune response of the human body. The proteolytic cleavage by aspartic proteases and the linkage with the membrane protein Msb2 are an example of resistant mechanisms related to salivary peptide histatin-5. This peptide can be degraded by $C$. albicans extracellular enzymes such as the aspartyl-proteases Sap2 $p$ and Sap5p. Beyond that, the polyamine efflux transporters FLU1 can cause the efflux of this peptide and stop its antifungal action. However, there are strategies to avoid these resistance mechanisms and increase the antifungal potential of this peptide and also to promote the escape of these resistance mechanisms. We can highlight here the production of histatin- 5 analogs like P113, dh-5, K11R-K17R and others that could be seen in Table 1 in this review. The alteration of their amino acid sequence and their fusion with other peptides are some strategies to avoid this resistance mechanisms shown for $C$. albicans. In fact, there are many works that show the development of new analogs and peptides based on histatin-5, but there are few works that describe their use in clinical treatment or in vivo experiments. The easy degradation by proteolytic enzymes is still a barrier for their applications that must be overcome.

In the light of these observations, we bring here the nanotechnology, specifically the NPs, as a suitable strategy to promote the clinical use for these peptides. Nanoparticles like liposomes, polymeric NPs and chitosan NPs are the most used and have shown great potential for the clinical application of these peptides. Even though more studies are needed, as well as the development of other types of NPs to promote the encapsulation of these peptides, the use of protein delivery systems based in nanotechnology could be a promising way to cope with this limitation and to promote a step forward in the biotechnological field.

Author Contributions: C.R.Z., F.H.d.F. and S.S.G. wrote and revised the manuscript. All authors have read and agreed to the published version of the manuscript.

Funding: This research was funded by FAPESP, grant number 2018/03018-1.

Acknowledgments: C.R.Z., F.H.d.F. thank CAPES and CNPq foundations for Ph.D. and Master fellowship, respectively.

Conflicts of Interest: The authors declare no conflict of interest.

\section{References}

1. de Oliveira Santos, G.C.; Vasconcelos, C.C.; Lopes, A.J.; de Sousa Cartágenes, M.D.; do Nascimento, F.R.; Ramos, R.M.; Pires, E.R.; de Andrade, M.S.; Rocha, F.M.; de Andrade Monteiro, C. Candida infections and therapeutic strategies: Mechanisms of action for traditional and alternative agents. Front. Microbiol. 2018, 9 , 1-23. [CrossRef]

2. Lamoth, F.; Lockhart, S.R.; Berkow, E.L.; Calandra, T. Changes in the epidemiological landscape of invasive candidiasis. J. Antimicrob. Chemother. 2018, 73, i4-i13. [CrossRef]

3. Sardi, J.C.O.; Scorzoni, L.; Bernardi, T.; Fusco-Almeida, A.M.; Giannini, M.J.S.M. Candida species: Current epidemiology, pathogenicity, biofilm formation, natural antifungal products and new therapeutic options. J. Med. Microbiol. 2013, 62, 10-24. [CrossRef]

4. Calderone, R.A.; Fonzi, W.A. Virulence factors of Candida albicans. Trends Microbiol. 2001, 9, 327-335. [CrossRef]

5. Shoham, S.; Marr, K.A. Invasive fungal infections in solid organ transplant recipients. Future Microbiol. 2012, 7, 639-655. [CrossRef]

6. Vila, T.; Romo, J.A.; Pierce, C.G.; McHardy, S.F.; Saville, S.P.; Lopez-Ribot, J.L. Targeting Candida albicans filamentation for antifungal drug development. Virulence 2016, 8, 150-158. [CrossRef]

7. Shapiro, R.S.; Robbins, N.; Cowen, L.E. Regulatory circuitry governing fungal development, drug resistance, and disease. Microbiol. Mol. Biol. Rev. 2011, 75, 213-267. [CrossRef]

8. Berkow, E.L.; Lockhart, S.R. Fluconazole resistance in Candida species: A current perspective. Infect. Drug Resist. 2017, 10, 237-245. [CrossRef]

9. Oppenheim, F.G.; Xu, T.; McMillian, F.M.; Levitz, S.M.; Diamond, R.D.; Offner, G.D.; Troxler, R.F. Histatins, a novel family of histidine-rich proteins in human parotid secretion. Isolation, characterization, primary structure, and fungistatic effects on Candida albicans. J. Biol. Chem. 1988, 263, 7472-7477. 
10. Helmerhorst, E.J.; Breeuwer, P.; van't Hof, W.; Walgreen-Weterings, E.; Oomen, L.C.J.M.; Veerman, E.C.I.; Amerongen, A.V.N.; Abee, T. The cellular target of histatin 5 on Candida albicans is the energized mitochondrion. J. Biol. Chem. 1999, 274, 7286-7291. [CrossRef]

11. Dadar, M.; Tiwari, R.; Karthik, K.; Chakraborty, S.; Shahali, Y.; Dhama, K. Candida albicans-Biology, molecular characterization, pathogenicity, and advances in diagnosis and control—An update. Microb. Pathog. 2018, 117, 128-138. [CrossRef]

12. Vila, T.; Sultan, A.S.; Montelongo-Jauregui, D.; Jabra-Rizk, M.A. Oral candidiasis: A disease of opportunity. J. Fungi 2020, 6, 15. [CrossRef]

13. Calderone, R.A.; Clancy, C.J. Candida and Candidiasis, 2nd ed.; ASM Press: Washington, DC, USA, 2012; 536p.

14. Pfaller, M.A.; Diekema, D.J. Epidemiology of invasive candidiasis: A persistent public health problem. Clin. Microbiol. Rev. 2007, 20, 133-163. [CrossRef]

15. Canela, H.M.S.; Cardoso, B.; Vitali, L.H.; Coelho, H.C.; Martinez, R.; Ferreira, M.E.d.S. Prevalence, virulence factors and antifungal susceptibility of Candida spp. isolated from bloodstream infections in a tertiary care hospital in Brazil. Mycoses 2018, 61, 11-21. [CrossRef]

16. Lewis, M.A.O.; Williams, D.W. Diagnosis and management of oral candidosis. Br. Dent. J. 2017, $223,675-681$. [CrossRef]

17. Gulati, M.; Nobile, C.J. Candida albicans biofilms: Development, regulation, and molecular mechanisms. Microbes Infect. 2016, 18, 310-321. [CrossRef]

18. Nikou, S.A.; Kichik, N.; Brown, R.; Ponde, N.O.; Ho, J.; Naglik, J.R.; Richardson, J.P. Candida albicans interactions with mucosal surfaces during health and disease. Pathogens 2019, 8, 53. [CrossRef]

19. Witchley, J.N.; Penumetcha, P.; Abon, N.V.; Woolford, C.A.; Mitchell, A.P.; Noble, S.M. Candida albicans morphogenesis programs control the balance between gut commensalism and invasive infection. Cell Host Microbe 2019, 25, 432-443. [CrossRef]

20. Gaur, N.K.; Smith, R.L.; Klotz, S.A. Candida albicans and Saccharomyces cerevisiae expressing ALA1/ALS5 adhere to accessible threonine, serine, or alanine patches. Cell Commun. Adhes. 2002, 9, 45-57. [CrossRef]

21. Murciano, C.; Moyes, D.L.; Runglall, M.; Tobouti, P.; Islam, A.; Hoyer, L.L.; Naglik, J.R. Evaluation of the role of Candida albicans agglutinin-like sequence (ALS) proteins in human oral epithelial cell interactions. PLoS ONE 2012, 7, e33362. [CrossRef]

22. Silva-Dias, A.; Miranda, I.M.; Branco, J.; Monteiro-Soares, M.; Pina-Vaz, C.; Rodrigues, A.G. Adhesion, biofilm formation, cell surface hydrophobicity, and antifungal planktonic susceptibility: Relationship among Candida spp. Front. Microbiol. 2015, 6, 205. [CrossRef] [PubMed]

23. Tati, S.; Davidow, P.; McCall, A.; Hwang-Wong, E.; Rojas, I.G.; Cormack, B.; Edgerton, M. Candida glabrata binding to Candida albicans hyphae enables its development in oropharyngeal candidiasis. PLOS Pathog. 2016, 12, e1005522. [CrossRef] [PubMed]

24. Xu, H.; Sobue, T.; Bertolini, M.; Thompson, A.; Vickerman, M.; Nobile, C.J.; Dongari-Bagtzoglou, A. S. oralis activates the Efg1 filamentation pathway in C. albicans to promote cross-kingdom interactions and mucosal biofilms. Virulence 2017, 8, 1602-1617. [CrossRef] [PubMed]

25. Lipke, P.N.; Klotz, S.A.; Dufrene, Y.F.; Jackson, D.N.; Garcia-Sherman, M.C. Amyloid-like $\beta$-aggregates as force-sensitive switches in fungal biofilms and infections. Microbiol. Mol. Biol. Rev. 2017, 82, e0035-17. [CrossRef]

26. Moreno-Ruiz, E.; Galán-Díez, M.; Zhu, W.; Fernández-Ruiz, E.; D’Enfert, C.; Filler, S.G.; Cossart, P.; Veiga, E. Candida albicans internalization by host cells is mediated by a clathrin-dependent mechanism. Cell. Microbiol. 2009, 11, 1179-1189. [CrossRef]

27. Höfs, S.; Mogavero, S.; Hube, B. Interaction of Candida albicans with host cells: Virulence factors, host defense, escape strategies, and the microbiota. J. Microbiol. 2016, 54, 149-169. [CrossRef]

28. Swidergall, M.; Filler, S.G. Oropharyngeal candidiasis: Fungal invasion and epithelial cell responses. PLoS Pathog. 2017, 13, e1006056. [CrossRef]

29. Wächtler, B.; Citiulo, F.; Jablonowski, N.; Förster, S.; Dalle, F.; Schaller, M.; Wilson, D.; Hube, B. Candida albicans-epithelial interactions: Dissecting the roles of active penetration, induced endocytosis and host factors on the infection process. PLoS ONE 2012, 7, e36952. [CrossRef] 
30. Allert, S.; Förster, T.M.; Svensson, C.M.; Richardson, J.P.; Pawlik, T.; Hebecker, B.; Rudolphi, S.; Juraschitz, M.; Schaller, M.; Blagojevic, M.; et al. Candida albicans-induced epithelial damage mediates translocation through intestinal barriers. mBio 2018, 9, e00915-18. [CrossRef]

31. Sorgo, A.G.; Heilmann, C.J.; Brul, S.; de Koster, C.G.; Klis, F.M. Beyond the wall: Candida albicans secret(e)s to survive. FEMS Microbiol. Lett. 2013, 338, 10-17. [CrossRef]

32. Jabra-Rizk, M.A.; Kong, E.F.; Tsui, C.; Nguyen, M.H.; Clancy, C.J.; Fidel, P.L.; Noverr, M. Candida albicans pathogenesis: Fitting within the host-microbe damage response framework. Infect. Immun. 2016, 84, 2724-2739. [CrossRef]

33. Colina, A.R.; Aumont, F.; Deslauriers, N.; Belhumeur, P.; De Repentigny, L. Evidence for degradation of gastrointestinal mucin by Candida albicans secretory aspartyl proteinase. Infect. Immun. 1996, 64, 4514-4519. [CrossRef] [PubMed]

34. Villar, C.C.; Kashleva, H.; Nobile, C.J.; Mitchell, A.P.; Dongari-Bagtzoglou, A. Mucosal tissue invasion by Candida albicans is associated with E-cadherin degradation, mediated by transcription factor Rim101p and protease Sap5p. Infect. Immun. 2007, 75, 2126-2135. [CrossRef] [PubMed]

35. Schaller, M.; Borelli, C.; Korting, H.C.; Hube, B. Hydrolytic enzymes as virulence factors of Candida albicans. Mycoses 2005, 48, 365-377. [CrossRef] [PubMed]

36. Meiller, T.F.; Hube, B.; Schild, L.; Shirtliff, M.E.; Scheper, M.A.; Winkler, R.; Ton, A.; Jabra-Rizk, M.A. A novel immune evasion strategy of Candida albicans: Proteolytic cleavage of a salivary antimicrobial peptide. PLoS ONE 2009, 4, e5039. [CrossRef]

37. Swidergall, M.; Ernst, A.M.; Ernst, J.F. Candida albicans mucin Msb2 is a broad-range protectant against antimicrobial peptides. Antimicrob. Agents Chemother. 2013, 57, 3917-3922. [CrossRef]

38. Moyes, D.L.; Wilson, D.; Richardson, J.P.; Mogavero, S.; Tang, S.X.; Wernecke, J.; Höfs, S.; Gratacap, R.L.; Robbins, J.; Runglall, M.; et al. Candidalysin is a fungal peptide toxin critical for mucosal infection. Nature 2016, 532, 64-68. [CrossRef]

39. Valitutti, F.; Cucchiara, S.; Fasano, A. Celiac disease and the microbiome. Nutrients 2019, 11, 2403. [CrossRef]

40. Imran, S.; Neeland, M.R.; Shepherd, R.; Messina, N.; Perrett, K.P.; Netea, M.G.; Curtis, N.; Saffery, R.; Novakovic, B. A Potential role for epigenetically mediated trained immunity in food allergy. iScience 2020, 23, 1-14. [CrossRef]

41. Ho, S.-M.; Lewis, J.D.; Mayer, E.A.; Bernstein, C.N.; Plevy, S.E.; Chuang, E.; Rappaport, S.M.; Croitoru, K.; Korzenik, J.R.; Krischer, J.; et al. Challenges in IBD Research: Environmental Triggers. Inflamm. Bowel Dis. 2019, 25, S13-S23. [CrossRef]

42. Corouge, M.; Loridant, S.; Fradin, C.; Salleron, J.; Damiens, S.; Moragues, M.D.; Souplet, V.; Jouault, T.; Robert, R.; Dubucquoi, S.; et al. Humoral immunity links Candida albicans infection and Celiac Disease. PLoS ONE 2015, 10, e121776. [CrossRef] [PubMed]

43. Tsui, C.; Kong, E.F.; Jabra-Rizk, M.A. Pathogenesis of Candida albicans Biofilm. Pathog. Dis. 2016, 74. [CrossRef] [PubMed]

44. D'Enfert, C. Biofilms and their role in the resistance of pathogenic Candida to antifungal agents. Curr. Drug Targets 2006, 7, 465-670. [CrossRef] [PubMed]

45. Hamet, M.; Pavon, A.; Dalle, F.; Pechinot, A.; Prin, S.; Quenot, J.P.; Charles, P.E. Candida spp. airway colonization could promote antibiotic-resistant bacteria selection in patients with suspected ventilator-associated pneumonia. Intensive Care Med. 2012, 38, 1272-1279. [CrossRef] [PubMed]

46. Hirota, K.; Yumoto, H.; Sapaar, B.; Matsuo, T.; Ichikawa, T.; Miyake, Y. Pathogenic factors in Candida biofilm-related infectious diseases. J. Appl. Microbiol. 2017, 122, 321-330. [CrossRef]

47. Jabra-Rizk, M.A. Pathogenesis of polymicrobial biofilms. Open Mycol. J. 2011, 5, 39-43. [CrossRef]

48. Zero, D.T.; Fontana, M.; Martínez-Mier, A.E.; Ferreira-Zandoná, A.; Ando, M.; González-Cabezas, C.; Bayne, S. The biology, prevention, diagnosis and treatment of dental caries: Scientific advances in the United States. J. Am. Dent. Assoc. 2009, 140, 25-34. [CrossRef]

49. Klein, M.I.; Hwang, G.; Santos, P.H.S.; Campanella, O.H.; Koo, H. Streptococcus mutans-derived extracellular matrix in cariogenic oral biofilms. Front. Cell. Infect. Microbiol. 2015, 5, 10. [CrossRef] 
50. Cavalcanti, I.M.; Nobbs, A.H.; Ricomini-Filho, A.P.; Jenkinson, H.F.; Del Bel Cury, A.A. Interkingdom Cooperation between Candida albicans, Streptococcus oralis and Actinomyces oris modulates early biofilm development on denture material. Pathog. Dis. 2016, 74. [CrossRef]

51. Xu, H.; Sobue, T.; Thompson, A.; Xie, Z.; Poon, K.; Ricker, A.; Cervantes, J.; Diaz, P.I.; Dongari-Bagtzoglou, A. Streptococcal co-infection augments Candida pathogenicity by amplifying the mucosal inflammatory response. Cell. Microbiol. 2014, 16, 214-231. [CrossRef]

52. Montelongo-Jauregui, D.; Lopez-Ribot, J.L. Candida interactions with the oral bacterial microbiota. J. Fungi 2018, 4, 122. [CrossRef]

53. Chinnici, J.; Yerke, L.; Tsou, C.; Busarajan, S.; Mancuso, R.; Sadhak, N.D.; Kim, J.; Maddi, A. Candida albicans cell wall integrity transcription factors regulate polymicrobial biofilm formation with Streptococcus gordonii. PeerJ 2019, 7, e7870. [CrossRef] [PubMed]

54. Hogan, D.A.; Kolter, R. Pseudomonas-Candida interactions: An ecological role for virulence factors. Science 2002, 296, 2229-2232. [CrossRef] [PubMed]

55. Wu, T.; Cen, L.; Kaplan, C.; Zhou, X.; Lux, R.; Shi, W.; He, X. Cellular components mediating coadherence of Candida albicans and Fusobacterium nucleatum. J. Dent. Res. 2015, 94, 1432-1438. [CrossRef] [PubMed]

56. Bor, B.; Cen, L.; Agnello, M.; Shi, W.; He, X. Morphological and physiological changes induced by contact-dependent interaction between Candida albicans and Fusobacterium nucleatum. Sci. Rep. 2016, 6, 27956. [CrossRef] [PubMed]

57. Sultan, A.S.; Kong, E.F.; Rizk, A.M.; Jabra-Rizk, M.A. The oral microbiome: A lesson in coexistence. PLoS Pathog. 2018, 14, e1006719. [CrossRef] [PubMed]

58. Kragelund, C. Exploiting new knowledge of Candidal infection for future antifungal combat. Oral Dis. 2017, 23, 543-547. [CrossRef]

59. Naglik, J.R.; König, A.; Hube, B.; Gaffen, S.L. Candida albicans-epithelial interactions and induction of mucosal innate immunity. Curr. Opin. Microbiol. 2017, 40, 104-112. [CrossRef]

60. Richardson, J.P.; Moyes, D.L.; Ho, J.; Naglik, J.R. Candida innate immunity at the mucosa. Semin. Cell Dev. Biol. 2019, 89, 58-70. [CrossRef]

61. Diamond, G.; Ryan, L.K. Beta-defensins: What are they REALLY doing in the oral cavity? Oral Dis. 2011, 17, 628-635. [CrossRef]

62. Tsai, P.W.; Yang, C.Y.; Chang, H.T.; Lan, C.Y. Human antimicrobial peptide LL-37 inhibits adhesion of Candida albicans by interacting with yeast cell-wall carbohydrates. PLoS ONE 2011, 6, e17755. [CrossRef] [PubMed]

63. Nikawa, H.; Samaranayake, L.P.; Tenovuo, J.; Pang, K.M.; Hamada, T. The fungicidal effect of human lactoferrin on Candida albicans and Candida krusei. Arch. Oral Biol. 1993, 38, 1057-1063. [CrossRef]

64. Kirkpatrick, C.H.; Green, I.; Rich, R.R.; Schade, A.L. Inhibition of growth of Candida albicans by iron-unsaturated lactoferrin: Relation to host-defense mechanisms in chronic mucocutaneous candidiasis. J. Infect. Dis. 1971, 124, 539-544. [CrossRef] [PubMed]

65. Lin, L.; Ibrahim, A.S.; Xu, X.; Farber, J.M.; Avanesian, V.; Baquir, B.; Fu, Y.; French, S.W.; Edwards, J.E.; Spellberg, B. Th1-Th17 cells mediate protective adaptive immunity against Staphylococcus aureus and Candida albicans infection in mice. PLoS Pathog. 2009, 5, e1000703. [CrossRef]

66. Hernández-Santos, N.; Huppler, A.R.; Peterson, A.C.; Khader, S.A.; McKenna, K.C.; Gaffen, S.L. Th17 cells confer long-term adaptive immunity to oral mucosal Candida albicans infections. Mucosal Immunol. 2013, 6, 900-910. [CrossRef] [PubMed]

67. Khan, S.A.; Fidel, P.L.; Al Thunayyan, A.; Varlotta, S.; Meiller, T.F.; Jabra-Rizk, M.A. Impaired histatin-5 levels and salivary antimicrobial activity against C. albicans in HIV infected individuals. J. AIDS Clin. Res. 2013, 4, 1000193. [CrossRef]

68. Cassone, A.; Cauda, R. Candida and candidiasis in HIV-infected patients: Where commensalism, opportunistic behavior and frank pathogenicity lose their borders. AIDS 2012, 26, 1457-1472. [CrossRef]

69. Perfect, J.R. The antifungal pipeline: A reality check. Nat. Rev. Drug Discov. 2017, 16, 603-616. [CrossRef]

70. Robbins, N.; Caplan, T.; Cowen, L.E. Molecular evolution of antifungal drug resistance. Annu. Rev. Microbiol. 2017, 71, 753-775. [CrossRef] 
71. Revie, N.M.; Iyer, K.R.; Robbins, N.; Cowen, L.E. Antifungal drug resistance: Evolution, mechanisms and impact. Curr. Opin. Microbiol. 2018, 45, 70-76. [CrossRef]

72. Parker, J.E.; Warrilow, A.G.S.; Price, C.L.; Mullins, J.G.L.; Kelly, D.E.; Kelly, S.L. Resistance to antifungals that target CYP51. J. Chem. Biol. 2014, 7, 143-161. [CrossRef] [PubMed]

73. Vincent, B.M.; Lancaster, A.K.; Scherz-Shouval, R.; Whitesell, L.; Lindquist, S. Fitness trade-offs restrict the evolution of resistance to amphotericin B. PLoS Biol. 2013, 11, e1001692. [CrossRef] [PubMed]

74. Bondaryk, M.; Kurzatkowski, W.; Staniszewska, M. Antifungal agents commonly used in the superficial and mucosal candidiasis treatment: Mode of action and resistance development. Postep. Dermatol. Alergol. 2013, 30, 293-301. [CrossRef] [PubMed]

75. Pfaller, M.A.; Rhomberg, P.R.; Messer, S.A.; Jones, R.N.; Castanheira, M. Isavuconazole, micafungin, and 8 comparator antifungal agents' susceptibility profiles for common and uncommon opportunistic fungi collected in 2013: Temporal analysis of antifungal drug resistance using CLSI species-specific clinical breakpoints and proposed epidemiological cutoff values. Diagn. Microbiol. Infect. Dis. 2015, 82, 303-313. [CrossRef] [PubMed]

76. Cleveland, A.A.; Farley, M.M.; Harrison, L.H.; Stein, B.; Hollick, R.; Lockhart, S.R.; Magill, S.S.; Derado, G.; Park, B.J.; Chiller, T.M. Changes in incidence and antifungal drug resistance in candidemia: Results from population-based laboratory surveillance in Atlanta and Baltimore, 2008-2011. Clin. Infect. Dis. 2012, 55, 1352-1361. [CrossRef] [PubMed]

77. Lockhart, S.R.; Etienne, K.A.; Vallabhaneni, S.; Farooqi, J.; Chowdhary, A.; Govender, N.P.; Colombo, A.L.; Calvo, B.; Cuomo, C.A.; Desjardins, C.A.; et al. Simultaneous emergence of multidrug-resistant Candida auris on 3 continents confirmed by whole-genome sequencing and epidemiological analyses. Clin. Infect. Dis. 2017, 64, 134-140. [CrossRef]

78. Pfaller, M.A.; Diekema, D.J.; Gibbs, D.L.; Newell, V.A.; Nagy, E.; Dobiasova, S.; Rinaldi, M.; Barton, R.; Veselov, A.; Finquelievich, J.; et al. Candida krusei, a multidrug-resistant opportunistic fungal pathogen: Geographic and temporal trends from the ARTEMIS DISK Antifungal Surveillance Program, 2001 to 2005. J. Clin. Microbiol. 2008, 46, 515-521. [CrossRef]

79. Park, S.; Kelly, R.; Kahn, J.N.; Robles, J.; Hsu, M.J.; Register, E.; Li, W.; Vyas, V.; Fan, H.; Abruzzo, G.; et al. Specific substitutions in the echinocandin target Fks1p account for reduced susceptibility of rare laboratory and clinical Candida sp. isolates. Antimicrob. Agents Chemother. 2005, 49, 3264-3273. [CrossRef]

80. Warrilow, A.G.S.; Martel, C.M.; Parker, J.E.; Melo, N.; Lamb, D.C.; Nes, W.D.; Kelly, D.E.; Kelly, S.L. Azole binding properties of Candida albicans sterol 14-alpha demethylase (CaCYP51). Antimicrob. Agents Chemother. 2010, 54, 4235-4245. [CrossRef]

81. Sanglard, D.; Ischer, F.; Koymans, L.; Bille, J. Amino acid substitutions in the cytochrome P-450 lanosterol 14- $\alpha$-demethylase (CYP51A1) from azole-resistant Candida albicans clinical isolates contribute to resistance to azole antifungal agents. Antimicrob. Agents Chemother. 1998, 42, 241-253. [CrossRef]

82. Singh-Babak, S.D.; Babak, T.; Diezmann, S.; Hill, J.A.; Xie, J.L.; Chen, Y.L.; Poutanen, S.M.; Rennie, R.P.; Heitman, J.; Cowen, L.E. Global analysis of the evolution and mechanism of echinocandin resistance in Candida glabrata. PLoS Pathog. 2012, 8, e1002718. [CrossRef] [PubMed]

83. Martel, C.M.; Parker, J.E.; Bader, O.; Weig, M.; Gross, U.; Warrilow, A.G.S.; Rolley, N.; Kelly, D.E.; Kelly, S.L. Identification and characterization of four azole-resistant erg3 mutants of Candida albicans. Antimicrob. Agents Chemother. 2010, 54, 4527-4533. [CrossRef] [PubMed]

84. Cowen, L.E.; Sanglard, D.; Howard, S.J.; Rogers, P.D.; Perlin, D.S. Mechanisms of antifungal drug resistance. Cold Spring Harb. Perspect. Med. 2015, 5, a019752. [CrossRef] [PubMed]

85. Prasad, R.; Goffeau, A. Yeast ATP-binding cassette transporters conferring multidrug resistance. Annu. Rev. Microbiol. 2012, 66, 39-63. [CrossRef]

86. Pao, S.S.; Paulsen, I.T.; Saier, M.H. Major facilitator superfamily. Microbiol. Mol. Biol. Rev. 1998, 62, 1-34. [CrossRef]

87. Wirsching, S.; Michel, S.; Morschhäuser, J. Targeted gene disruption in Candida albicans wild-type strains: The role of the MDR1 gene in fluconazole resistance of clinical Candida albicans isolates. Mol. Microbiol. 2000, 36, 856-865. [CrossRef]

88. Zasloff, M. Antimicrobial peptides of multicellular organisms. Nature 2002, 415, 389-395. [CrossRef] 
89. Oshiro, K.G.N.; Rodrigues, G.; Monges, B.E.D.; Cardoso, M.H.; Franco, O.L. Bioactive peptides against fungal biofilms. Front. Microbiol. 2019, 10, 1-17. [CrossRef]

90. Baev, D.; Li, X.S.; Dong, J.; Keng, P.; Edgerton, M. Human salivary histatin 5 causes disordered volume regulation and cell cycle arrest in Candida albicans. Infect. Immun. 2002, 70, 4777-4784. [CrossRef]

91. Helmerhorst, E.J.; Alagl, A.S.; Siqueira, W.L.; Oppenheim, F.G. Oral fluid proteolytic effects on histatin 5 structure and function. Arch. Oral Biol. 2006, 51, 1061-1070. [CrossRef]

92. Seo, M.-D.; Won, H.-S.; Kim, J.-H.; Mishig-Ochir, T.; Lee, B.-J. Antimicrobial peptides for therapeutic applications: A review. Molecules 2012, 17, 12276-12286. [CrossRef] [PubMed]

93. Campese, M.; Sun, X.; Bosch, J.A.; Oppenheim, F.G.; Helmerhorst, E.J. Concentration and fate of histatins and acidic proline-rich proteins in the oral environment. Arch. Oral Biol. 2009, 54, 345-353. [CrossRef] [PubMed]

94. Konopka, K.; Dorocka-Bobkowska, B.; Gebremedhin, S.; Düzgüneş, N. Susceptibility of Candida biofilms to histatin 5 and fluconazole. Antonie Van Leeuwenhoek 2010, 97, 413-417. [CrossRef] [PubMed]

95. Moffa, E.B.; Mussi, M.C.M.; Xiao, Y.; Garrido, S.S.; Machado, M.A.A.M.; Giampaolo, E.T.; Siqueira, W.L. Histatin 5 inhibits adhesion of C. albicans to reconstructed human oral epithelium. Front. Microbiol. 2015, 6, 885. [CrossRef]

96. Han, J.; Jyoti, M.A.; Song, H.-Y.; Jang, W.S. Antifungal activity and action mechanism of histatin 5-halocidin hybrid peptides against Candida ssp. PLoS ONE 2016, 11, e0150196. [CrossRef]

97. Puri, S.; Edgerton, M. How does it kill? Understanding the candidacidal mechanism of salivary histatin 5. Eukaryot. Cell 2014, 13, 958-964. [CrossRef]

98. Park, S.-C.; Kim, Y.-M.; Lee, J.-K.; Kim, N.-H.; Kim, E.-J.; Heo, H.; Lee, M.-Y.; Lee, J.R.; Jang, M.-K. Targeting and synergistic action of an antifungal peptide in an antibiotic drug-delivery system. J. Control. Release 2017, 256, 46-55. [CrossRef]

99. Basso, V.; Garcia, A.; Tran, D.Q.; Schaal, J.B.; Tran, P.; Ngole, D.; Aqeel, Y.; Tongaonkar, P.; Ouellette, A.J.; Selsted, M.E. Fungicidal potency and mechanisms of $\theta$-defensins against multidrug-resistant Candida species. Antimicrob. Agents Chemother. 2018, 62, 1-16. [CrossRef]

100. Pathirana, R.U.; Friedman, J.; Norris, H.L.; Salvatori, O.; McCall, A.D.; Kay, J.; Edgerton, M. Fluconazole-resistant Candida auris is susceptible to salivary histatin 5 killing and to intrinsic host defenses. Antimicrob. Agents Chemother. 2018, 62, 1-11. [CrossRef]

101. Du, H.; Puri, S.; McCall, A.; Norris, H.L.; Russo, T.; Edgerton, M. Human salivary protein histatin 5 has potent bactericidal activity against ESKAPE pathogens. Front. Cell. Infect. Microbiol. 2017, 7, 1-12. [CrossRef]

102. Melino, S.; Santone, C.; Di Nardo, P.; Sarkar, B. Histatins: Salivary peptides with copper (II)- and zinc (II)-binding motifs. FEBS J. 2014, 281, 657-672. [CrossRef] [PubMed]

103. Conklin, S.E.; Bridgman, E.C.; Su, Q.; Riggs-Gelasco, P.; Haas, K.L.; Franz, K.J. Specific histidine residues confer histatin peptides with copper-dependent activity against Candida albicans. Biochemistry 2017, 56, 4244-4255. [CrossRef] [PubMed]

104. Puri, S.; Li, R.; Ruszaj, D.; Tati, S.; Edgerton, M. Iron binding modulates candidacidal properties of salivary histatin 5. J. Dent. Res. 2015, 94, 201-208. [CrossRef] [PubMed]

105. Puri, S.; Friedman, J.; Saraswat, D.; Kumar, R.; Li, R.; Ruszaj, D.; Edgerton, M. Candida albicans Shed Msb2 and host mucins affect the candidacidal activity of salivary Hst 5. Pathogens 2015, 4, 752-763. [CrossRef] [PubMed]

106. Szafranski-Schneider, E.; Swidergall, M.; Cottier, F.; Tielker, D.; Román, E.; Pla, J.; Ernst, J.F. Msb2 shedding protects Candida albicans against antimicrobial peptides. PLoS Pathog. 2012, 8, e1002501. [CrossRef]

107. Li, R.; Kumar, R.; Tati, S.; Puri, S.; Edgerton, M. Candida albicans Flu1-mediated efflux of salivary histatin 5 reduces its cytosolic concentration and fungicidal activity. Antimicrob. Agents Chemother. 2013, 57, 1832-1839. [CrossRef]

108. Hampe, I.A.I.; Friedman, J.; Edgerton, M.; Morschhäuser, J. An acquired mechanism of antifungal drug resistance simultaneously enables Candida albicans to escape from intrinsic host defenses. PLoS Pathog. 2017, 13, e1006655. [CrossRef]

109. Perlin, D.S.; Rautemaa-Richardson, R.; Alastruey-Izquierdo, A. The global problem of antifungal resistance: Prevalence, mechanisms, and management. Lancet Infect. Dis. 2017, 17, e383-e392. [CrossRef] 
110. Helmerhorst, E.J.; van't Hof, W.; Veerman, E.C.I.; Simoons-Smit, I.; Amerongen, A.V.N. Synthetic histatin analogues with broad-spectrum antimicrobial activity. Biochem. J. 1997, 326, 39-45. [CrossRef]

111. Helmerhorst, E.J.; van't Hof, W.; Breeuwer, P.; Veerman, E.C.I.; Abee, T.; Troxler, R.F.; Amerongen, A.V.N.; Oppenheim, F.G. Characterization of histatin 5 with respect to amphipathicity, hydrophobicity, and effects on cell and mitochondrial membrane integrity excludes a candidacidal mechanism of pore formation. J. Biol. Chem. 2001, 276, 5643-5649. [CrossRef]

112. den Hertog, A.L.; Sang, H.W.; Kraayenhof, R.; Bolscher, J.G.M.; Hof, W.V.; Veerman, E.C.; Amerongen, A.V. Interactions of histatin 5 and histatin 5-derived peptides with liposome membranes: Surface effects, translocation and permeabilization. Biochem. J. 2004, 379, 665-672. [CrossRef] [PubMed]

113. Faber, C.; Stallmann, H.P.; Lyaruu, D.M.; De Blieck, J.M.; Bervoets, T.J.; van Nieuw Amerongen, A.; Wuisman, P.I. Release of antimicrobial peptide Dhvar-5 from polymethylmethacrylate beads. J. Antimicrob. Chemother. 2003, 51, 1359-1364. [CrossRef] [PubMed]

114. Lu, X.; Wan, L.; Yang, H.; Zhang, J.; Li, S.; Kang, M.; Li, Y.; Cheng, J. Fusion of fungicidal peptide dhvar4 to enterococcal peptide pheromone increases its bactericidal activity against Enterococcus faecalis. Chem. Biol. Drug Des. 2006, 68, 220-224. [CrossRef] [PubMed]

115. Basiri, T.; Johnson, N.D.; Moffa, E.B.; Mulyar, Y.; Serra Nunes, P.L.; Machado, M.A.A.M.; Siqueira, W.L. Duplicated or hybridized peptide functional domains promote oral homeostasis. J. Dent. Res. 2017, 96, 1162-1167. [CrossRef] [PubMed]

116. Ikonomova, S.P.; Moghaddam-Taaheri, P.; Jabra-Rizk, M.A.; Wang, Y.; Karlsson, A.J. Engineering improved variants of the antifungal peptide histatin 5 with reduced susceptibility to Candida albicans secreted aspartic proteases and enhanced antimicrobial potency. FEBS J. 2017, 285, 146-159. [CrossRef] [PubMed]

117. Ikonomova, S.P.; Moghaddam-Taaheri, P.; Wang, Y.; Doolin, M.T.; Stroka, K.M.; Hube, B.; Karlsson, A.J. Effects of histatin 5 modifications on antifungal activity and kinetics of proteolysis. Protein Sci. 2019, 29, 480-493. [CrossRef]

118. Jephthah, S.; Henriques, J.; Cragnell, C.; Puri, S.; Edgerton, M.; Skepö, M. Structural characterization of histatin 5-spermidine conjugates: A combined experimental and theoretical study. J. Chem. Inf. Model. 2017, 57, 1330-1341. [CrossRef]

119. Moffa, E.B.; Machado, M.A.A.M.; Mussi, M.C.M.; Xiao, Y.; Garrido, S.S.; Giampaolo, E.T.; Siqueira, W.L. In vitro identification of histatin 5 salivary complexes. PLoS ONE 2015, 10, e142517. [CrossRef]

120. Tati, S.; Li, R.; Puri, S.; Kumar, R.; Davidow, P.; Edgerton, M. Histatin 5-spermidine conjugates have enhanced fungicidal activity and efficacy as a topical therapeutic for oral candidiasis. Antimicrob. Agents Chemother. 2014, 58, 756-766. [CrossRef]

121. Voltan, A.; Quindós, G.; Alarcón, K.; Fusco-Almeida, A.M.; Mendes-Giannini, M.J.; Chorilli, M. Fungal diseases: Could nanostructured drug delivery systems be a novel paradigm for therapy? Int. J. Nanomedicine 2016, 11, 3715-3730. [CrossRef]

122. Ron-Doitch, S.; Sawodny, B.; Kühbacher, A.; David, M.M.N.; Samanta, A.; Phopase, J.; Burger-Kentischer, A.; Griffith, M.; Golomb, G.; Rupp, S. Reduced cytotoxicity and enhanced bioactivity of cationic antimicrobial peptides liposomes in cell cultures and 3D epidermis model against HSV. J. Control. Release 2016, 229, 163-171. [CrossRef] [PubMed]

123. Salade, L.; Wauthoz, N.; Deleu, M.; Vermeersch, M.; De Vriese, C.; Amighi, K.; Goole, J. Development of coated liposomes loaded with ghrelin for nose-to-brain delivery for the treatment of cachexia. Int. J. Nanomed. 2017, 12, 8531-8543. [CrossRef] [PubMed]

124. Cao, S.; Xu, S.; Wang, H.; Ling, Y.; Dong, J.; Xia, R.; Sun, X. Nanoparticles: Oral delivery for protein and peptide drugs. AAPS PharmSciTech 2019, 20, 190. [CrossRef] [PubMed]

125. Myerson, J.; He, L.; Lanza, G.; Tollefsen, D.; Wickline, S. Thrombin-inhibiting perfluorocarbon nanoparticles provide a novel strategy for the treatment and magnetic resonance imaging of acute thrombosis. J. Thromb. Haemost. 2011, 9, 1292-1300. [CrossRef]

126. Lee, E.H.; Khan, I.; Oh, D.-H. Evaluation of the efficacy of nisin-loaded chitosan nanoparticles against foodborne pathogens in orange juice. J. Food Sci. Technol. 2018, 55, 1127-1133. [CrossRef] 
127. Lin, Z.; Li, R.; Liu, Y.; Zhao, Y.; Ao, N.; Wang, J.; Li, L.; Wu, G. Histatin1-modified thiolated chitosan hydrogels enhance wound healing by accelerating cell adhesion, migration and angiogenesis. Carbohydr. Polym. 2020, 230, 115710. [CrossRef]

128. Kong, E.F.; Tsui, C.; Boyce, H.; Ibrahim, A.; Hoag, S.W.; Karlsson, A.J.; Meiller, T.F.; Jabra-Rizk, M.A. Development and in vivo evaluation of a novel histatin-5 bioadhesive hydrogel formulation against oral candidiasis. Antimicrob. Agents Chemother. 2016, 60, 881-889. [CrossRef]

129. Sultan, A.S.; Vila, T.; Hefni, E.; Karlsson, A.J.; Jabra-Rizk, M.A. Evaluation of the antifungal and wound-healing properties of a novel peptide-based bioadhesive hydrogel formulation. Antimicrob. Agents Chemother. 2019, 63, 1-11. [CrossRef]

130. Sultan, A.S.; Rizk, A.M.; Vila, T.; Ji, Y.; Masri, R.; Jabra-Rizk, M.A. Digital design of a universal rat intraoral device for therapeutic evaluation of a topical formulation against candida-associated denture stomatitis. Infect. Immun. 2019, 87, 1-14. [CrossRef]

131. Wen, J.; Yeh, C.-K.; Sun, Y. Salivary polypeptide/hyaluronic acid multilayer coatings act as "fungal repellents" and prevent biofilm formation on biomaterials. J. Mater. Chem. 2018, 6, 1452-1457. [CrossRef]

132. Bates, A.; Garaicoa, J.; Fischer, C.; Brogden, K. Diminished antimicrobial peptide and antifungal antibiotic activities against Candida albicans in denture adhesive. Antibiotics 2017, 6, 6. [CrossRef] [PubMed]

133. Jang, W.S.; Li, X.S.; Sun, J.N.; Edgerton, M. The P-113 fragment of histatin 5 requires a specific peptide sequence for intracellular translocation in Candida albicans, which is independent of cell wall binding. Antimicrob. Agents Chemother. 2008, 52, 497-504. [CrossRef] [PubMed]

134. Zambom, C.R.; da Fonseca, F.H.; Crusca, E.; da Silva, P.B.; Pavan, F.R.; Chorilli, M.; Garrido, S.S. A novel antifungal system with potential for prolonged delivery of histatin 5 to limit growth of Candida albicans. Front. Microbiol. 2019, 10. [CrossRef] [PubMed]

(C) 2020 by the authors. Licensee MDPI, Basel, Switzerland. This article is an open access article distributed under the terms and conditions of the Creative Commons Attribution (CC BY) license (http://creativecommons.org/licenses/by/4.0/). 